\title{
Push your luck!
}

\author{
From the Minimally Invasive Cardiac Surgery Department, Istituto Clinico Sant'Ambrogio, Gruppo Ospedaliero \\ San Donato, Milan, Italy. \\ Disclosures: Authors have nothing to disclose with regard to commercial support. \\ Received for publication Sept 23, 2018; accepted for publication Sept 24, 2018; available ahead of print Nov 3 , \\ 2018. \\ Address for reprints: Antonio Miceli, MD, PhD, Minimally Invasive Cardiac Surgery Department, Istituto Clinico \\ Sant'Ambrogio, Via Faravelli 16, Milano, 20146 Italy (E-mail: antoniomiceli79@alice.it). \\ J Thorac Cardiovasc Surg 2019;157:e33-4 \\ $0022-5223 / \$ 36.00$ \\ Copyright (C) 2018 by The American Association for Thoracic Surgery \\ https://doi.org/10.1016/j.jtcvs.2018.09.079
}

Mitral valve repair is the gold standard treatment for degenerative mitral valve regurgitation. In the last decade, several minimally invasive mitral valve repair techniques have been developed to reduce the invasiveness of the surgical procedure, offering comparable safety and quality to the conventional approach, including high freedom from mitral valve reoperation. ${ }^{1}$ The implantation of artificial chordae has definitively contributed to these excellent results. ${ }^{2}$ The willingness to be less invasive has brought the idea of the NeoChord system (NeoChord, Inc, Minneapolis, Minn), an off-pump, transapical surgical option, for treating degenerative mitral valve disease on a beating heart.

In this issue of the Journal, 2 case reports describe 3 cases of late rupture of the NeoChord system after successful minimally invasive mitral valve repair through a transapical beating heart approach at 5, 12, and 30 months. ${ }^{3,4}$ The recurrences of severe mitral valve regurgitation required a conventional approach through a median sternotomy.

The rupture of expanded polytetrafluoroethylene (PTFE) neochordae is a rare complication in conventional mitral valve surgery. On conducting a literature review, Bortolotti and colleagues ${ }^{5}$ found only 4 cases of recurrent mitral regurgitation due to the late (6-14 years postoperatively) rupture of calcified expanded PTFE chordae. ${ }^{5}$ Conversely, the genesis of early chordal rupture was probably related to a PTFE fatigue-induced lesion. In 2014, Seeburger and colleagues ${ }^{6}$ presented the results of mitral valve repair using the NeoChord DS1000 system in the Transapical Artificial Chordae Tendinae trial. Of note, 2 procedure refinements were introduced during the conduct of the trial to reduce the mechanical stress: (1) the use of multiple neochordae per procedure to give an equal distribution of stress on mitral valve leaflet tissue and PTFE sutures and (2) the revision of the left ventricular apical access site toward the posterolateral wall. The latter provides a more natural orientation of implanted neochordae and shortens the length of artificial chordae, because the left ventricle anchoring point is closer to the base of the posterior papillary muscle. ventricle.

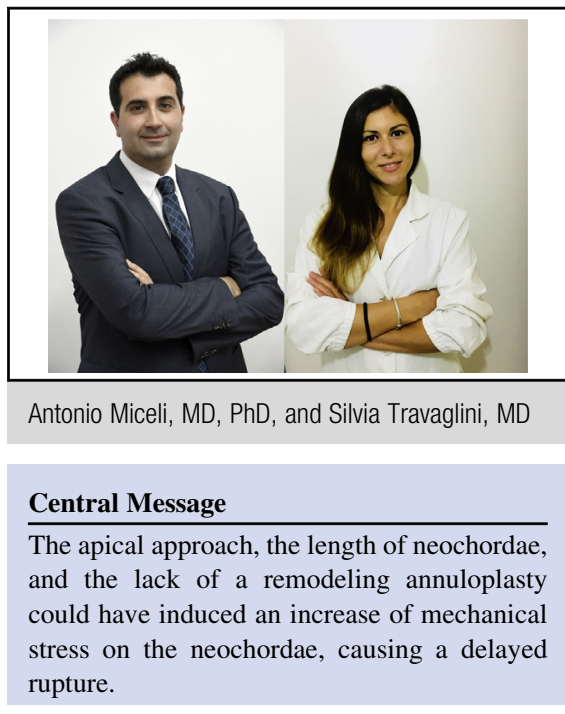

See Articles pages e23 and e27.

In an in vitro test, Caimmi and colleagues ${ }^{7}$ found that the increase of the length of artificial expanded PTFE chordae is accompanied by an increasing stiffness that may compromise the long-term resistance of the chordae, suggesting that mitral valve repairs that anchor expanded PTFE neochordae to the ventricular apex may have less durability than when anchored to the tips of the papillary muscles. In this setting, the mechanical stress induced by the "apex approach" might partially explain the failure of mitral valve repair. Furthermore, the early left ventricular reverse remodeling determines a shortening of the distance from the repaired mitral valve leaflet to the insertion point of the left ventricular wall and contributes further stress for the relative elongation of the neochorade. ${ }^{8}$ This "whip effect," generated by the excessive length, associated with the postoperative endothelialization process, determines the fusion of the neochordae, resulting in additional stiffening with consequent rupture. As a result, during the procedure, a final overtension of the leaflet is recommended, which shortens the neochorda length and may reduce the stress and recurrence of prolapse during the early remodeling of the left

Finally, the lack of stabilization of the entire annulus with a remodeling annuloplasty might have further increased the mechanical stress on the neochordae. A recent large European experience with transapical off-pump mitral valve repair with the NeoChord system reported a $96.7 \%$ rate success with acceptable postoperative complications. ${ }^{9}$ Although no chordal rupture occurred, Colli and 
colleagues $^{9}$ reported a $9 \%$ rate of redo surgery at 1 year. A limit of this procedure, considering that in large mitral repair centers, the recurrence of mitral regurgitation and mitral reoperation is low, between $5 \%$ and $10 \%$ at 10 years. $^{10,11}$ The NeoChord DS 1000 system was developed to reduce the invasiveness of the surgical procedure and avoid the cardiopulmonary bypass machine. However, results are still far from those conferred by a conventional minimally invasive approach.

\section{References}

1. Miceli A, Murzi M, Canarutto D, Gilmanov D, Ferrarini M, Farneti PA, et al. Minimally invasive mitral valve repair through right minithoracotomy in the setting of degenerative mitral regurgitation: early outcomes and long-term follow-up. Ann Cardiothorac Surg. 2015;4:422-7.

2. Perier P, Hohenberger W, Lakew F, Batz G, Urbanski P, Zacher M, et al. Toward a new paradigm for the reconstruction of posterior leaflet prolapse: midterm results of the "respect rather than resect" approach. Ann Thorac Surg. 2008;86:718-25.

3. Heuts S, Kawczynski M, Olsthoorn JR, Sardari P. Late rupture of transapically beating-heart implanted NeoChords. J Thorac Cardiovasc Surg. 2019; 157:e23-5
4. Grinberg D, Adamou Nouho K, Pozzi M, Obadia JF. Artificial mitral chordae; when length matters. J Thoracic Cardiovasc Surg. 2019;157: e27-9.

5. Bortolotti U, Celiento M, Pratali S, Anastasio G, Pucci A. Recurrent mitral regurgitation due to ruptured artificial chordae: case report and review of the literature. J Heart Valve Dis. 2012;21:440-3.

6. Seeburger J, Rinaldi M, Nielsen SL, Salizzoni S, Lange R, Schoenburg M, et al. Off-pump transapical implantation of artificial neo-chordae to correct mitral regurgitation: the TACT trial (transapical artificial chordae tendinae) proof of concept. J Am Coll Cardiol. 2014;63:914-9.

7. Caimmi PP, Sabbatini M, Fusaro L, Borrone A, Cannas M. A study of the mechanical properties of ePTFE suture used as artificial mitral chordae. J Card Surg. 2016:31:498-502

8. Kiefer P, Meier S, Noack T, Borger MA, Ender J, Hoyer A, et al. Good 5-year durability of transapical beating heart off-pump mitral valve repair with neochordae. Ann Thorac Surg. 2018;106:440-6.

9. Colli A, Manzan E, Aidietis A, Rucinskas K, Bizzotto E, Besola L, et al. An early European experience with transapical off-pump mitral valve repair with NeoChord implantation. Eur J Cardiothorac Surg. 2018;54:460-6.

10. Suri RM, Schaff HV, Dearani JA, Sundt TM III, Daly RC, Mullany CJ, et al. Survival advantage and improved durability of mitral repair for leaflet prolapse subsets in the current era. Ann Thorac Surg. 2006;82:819-26.

11. David TE, Ivanov J, Armstrong S, Christie D, Rakowski H. A comparison of outcomes of mitral valve repair for degenerative disease with posterior, anterior, and bileaflet prolapse. J Thorac Cardiovasc Surg. 2005;130:1242-9. 